\title{
A PROJETADA FERROVIA ENTRE O VALE DO PARAİBA E O MAR
}

Próximo a Bairro Alto deveria a estrada de ferro que de Taubaté seria construída até Ubatuba, atravessar o Paraibuna, à procura de um passo favorável naquelas alturas existente na Serra do Mar, a fim de que, transposta a principal linha de altitudes, pudesse, em rampa razoável, descer em rumo da cidade praiana.

Quem até poucos anos atrás pretendesse, por terra, dirigirse a Ubatuba, encontraria pela frente um percurso penoso e dificil de vencer. Nāo teria outro recurso senāo, em boa cavalgadura, percorrer as quase duas dezenas de léguas que de qualquer das cidades do Vale do Paraiba medeiam até beira-mar. E lá se iam, além de dois dias de viagem desconfortável, uma boa soma de energia trocada em cansaço. Se hoje existem duas estradas de rodagem, ligando o Vale ao Litoral - uma boa, outra regular essa regiāo compreendida pelas bacias dos formadores do Rio.Paraíba, de clima suave e bom, de solo fértil e propício a um sem número de cultivos, de gente acolhedora e resoluta, onde impera a tradiçāo e sobrevive a cordialidade, essa regiāo, como dizíamos, esteve a pique de possuir uma estrada de ferro que, sobretudo, teria a ela apresentado novas e melhores oportunidades de expansāo econômica durante o último meio século.

Em junho de 1875 a Estrada de Ferro D. Pedro II, lançada em direção da Capital paulista, a partir do Rio de Janeiro, alcançava a cidade de Cachoeira. A êsse tempo já se encontrava em franca atividade a Companhia Sāo Paulo e Rio de Janeiro, constituída para levar a efeito a ligaçāo ferroviária entre São Paulo e o ponto terminal da linha que se projetara Serra do Mar acima, por isso que, logo em novembro dêsse mesmo ano, estendia seus trilhos e iniciava o tráfego até Mogi das Cruzes. Em julho do ano seguinte chegava a Jacarei, em agôsto a São José dos Campos e a Taubaté em dezembro. Em janeiro de 1877 alcançava Pindamonhangaba, Guaratinguetá em maio e, finalmente, em julho, com 231 kms. de percurso, atingia Cachoeira, ligando, definitivamente, as duas grandes capitais.

Estabelecida a ligaçāo ferroviária de tôdas as cidades do Vale do Paraiba com a capital paulista, a presteza do tráfego e a facilidade do transporte, em contraposiçāo aos demorados e trabaIhosos meios de conduçāo até então existentes, que outros nāo 
eram senāo as tropas que entre Taubaté e Ubatuba carreavam a maior parte dos produtos de exportaçāo da zona, representados principalmente pelo café, fizeram com que a ferrovia drenasse, em direçāo ao pôrto de Santos, tôda a carga útil e disponivel da regiāo. Todos os produtos do Vale do Paraiba e do Sul de Minas, que aí vinham ter, e mesmo os do próprio Vale do Paraitinga, deixaram de procurar o pôrto de Ubatuba, em lombo de burro, para irem ter ao de Santos sôbre trilhos, onde desfrutariam de melhores condições de embarque e de maiores facilidades de comércio, por isso que ali já se encontravam instaladas as grandes firmas comerciais e as mais importantes casas comissárias de café.

Ubatuba, e com ela todo o litoral norte, iniciou um novo ciclo de decadência econômica, fenômeno cujas àmarguras já provara por mais de uma vez em sua história. Conta o dr. Esteves da Silva - médico e educador que fêz de Ubatuba a sua terra adotiva, e a quem esta deve muito de seu progresso material e cultural da época - em um de seus discursos parlamentares na Assembléia Paulista, como deputado estadual, em 1899, que num lampejo de vida, a regiāo procurou se recompor do impacto sofrido.

Quando ainda se planejava e organizava a estrada de ferro Sāo Paulo-Rio de Janeiro, já os fazendeiros da regiāo, prevendo - que sucederia tão logo a mesma entrasse em funcionamento, cuidaram de dar todo o apôio necessário para a construçāo de uma ferrovia que partindo de Ubatuba fôsse ter ao Vale do Paraíba. Graças ao prestígio das classes rurais litorâneas, Charles Bernard e Sebastiāo Gomes da Silva Belfort conseguiram obter do govêrno da Frovíncia, em 1874, uma concessāo para a construçāo de uma estrada de ferro entre Ubatuba e Guaratinguetá. Deveria ela subir a Serra pelo sistema de cremalheiras.

Ainda com o apôio dos fazendeiros da zona, submeteram os concessionários à Assembléia Provincial um pedido de garantia de juros para o capital empregado na construção da ferrovia. Muito embora a Assembléia concordasse com o pedido, recusou-se o Govêrno a assinar o contrato indispensável, exigido pela lei, sob a alegação de que a estrada, se assim o fizesse, sòmente prejuizos daria ao erário público. Estribara-se, a êsse respeito, em um parecer da Superintendencia das Estradas de Ferro de São Paulo. Marchas e contramarchas politicas de nada adiantaram.

Outra razāo alegada pelo então Presidente da Província, pa:a se negar a assinar o contrato de garantia de juros, era a de que nāo conseguiriam os construtores atravessar a Serra. A Serra do Mar, nessa altura, seria infranqueável.

A companhia nāo chegou a ser organizada, a construçāo da estrada nāo foi iniciada; prescreveram-se os prazos e, mais tarde, em 1897, o Presidente do Estado declarou caduca a concessāo. Já por essa época, o desencantado engenheiro Bernard, a nenhuma, 
porque na emprêsa empregara suas últimas economias, enlouqueceu e matou-se.

Esta, a versāo de Esteves da Silva. Segundo dados constantes de relatórios oficiais, o caso da primeira tentativa para ligar Ubatuba ao Vale do Paraíba foi o que narraremos a seguir.

Os cidadãos Charles Bernard e Sebastiāo Gomes da Silva Belfort obtiveram do Govêrno da Província a concessāo de "umá estrada de ferro econômica, por traçāo animada, de Lbatuba a: Guaratinguetá, com um ramal a Pindamonhangaba". Lavrado ó contrato com o Govêrno, em 29 de agôsto de 1874, pela cláusula $3 .^{\mathrm{a}}$ deviam os concessionários, no praso de 30 meses, a contar daquela data, organizar a companhia, se näo pudessem por si realizar a construçāo da estrada.

Nāo conseguiram os concessionários até o último dia de fevereiro de 1877 concretizar a incorporação da companhia e, dêsse mesmo dia em diante, portanto, começou a correr o prazo para o início das obras de construçāo, prazo êsse que deveria terminar em igual dia de fereveiro de 1879. Nesta última data já estavam os concessionários incursos na cláusula de caducidade

Garantias de juros tinham sido concedidas em 20 de marçó de 1875, pela Lei n. 8 , lei essa que nāo alterou os prazos do contrato, acima referido. E verdade que o presidente da Provincia recusara-se a assinar o contrato da garantia de juros, determinado pela Lei n. ${ }^{0}$ 8. Debalde, porém, pretenderam justificar, com issé? o nāo cumprimento dos prazos para construçāo, uma vez que a garantia de juros sòmente seria concretizada em relação ao capitạl empregado em obras que já tivessem sido executadas. Para que a garantia de juros se tornasse efetiva era indispensável que obras fôssem executadas e nelas empregado rapital, o que até entāo não ocorrera.

$\mathrm{Na}$ verdade, iniciadas as obras, empregado nelas certo capital, continuasse o presidente da Provínciz a se recusar a assinar o contrato, poderiam entāo os concessionários, recorrendo ao poder judiciário, defender os seus direitos.

Nada disso aconteceu. A companhia nāo foi organizada. As obras nāo tiveram início. Nada foi feito de concreto. Em vista disso, o Presidente do Estado, em data de 14 de agôsto de 1897, bais. xou o Decreto n. ${ }^{\circ} 469$, declarando caduco o contrato celebrado em 29 de agôsto de 1874, com Sebastiäo Gomes da Silva Belfort e Charles Bernard, para a construçāo de uma ferrovia, "de traçäo animada", entre Ubatuba e Guaratinguetá.

Diz ainda Esteves da Silva que Cox, um engenheiro inglês, ciente do fracassado projeto de construçāo de uma estrada de ferro entre Ubatuba e o Vale do Paraiba, tratou de por sua própria conta realizar estudos de campo, para resolver a dúvida suscitada de que a Serra do Mar, naquela altura, era infranqueável. E chegou a conclusões diametralmente opostas. A Serra daria passagem, 
e boa, ná aberta chamada Taquaruçú, aproveitada nos estudos que mais tarde seriam aprovados para a mesma ferrovia.

Cox e alguns companheiros, feitos os estudos preliminares, imaginaram, de início, dirigir-se a Londres, a fim de levantar os capitais indispensáveis à construçāo da estrada. Tal fato ocorreu, entretanto, na mesma ocasic̄o em que a febre de incorporações de companhias, no Brasil, estava prestes a atingir o auge - o Encilhamento. Por isso, em vez de procurar obter capitais inglêses, para êles próprios organizarem a companhia, preferiram, por maior prudência, vender os estudos realizados, fato que deu origem à formaçāo da Companhia de Estradas de Ferro Norte de Sāo Paulo.

Nāo sabemos ao certo como, mas o fato é que êsse negócio da estrada de ferro, entre Taubaté e Ubatuba, acabou indo parar nas māos de Francisco de Moura Escobar e Vitoriano Eugênio Marcondes Varela. A Lei n. ${ }^{0} 3.397$, de 24 de novembro de 1888 , que fixava a receita do Império para o exercício seguinte, autorizou o govêrno a conceder a garantia de juros de $6 \%$, até o custo máximo de 30 contos por quilômetro, a diversas estradas de ferro, entre elas a de Taubaté a Ubatuba, sendo de 30 anos o prazo máximo da concessāo.

Questāo de dois meses mais tarde, publicou o "Diário Oficial do Império do Brazil", em seu número de 26 de janeiro de 1889 , o Decreto n. ${ }^{0} 10.150$, de 5 de janeiro de 1889 , cujo texto declarava:

"Concede privilégio e garantia de juros para construção da Estrada de Ferro de Taubaté a Ubatuba na Provincia de Sāo Paulo.

"Atendendo ao que Me requereram o bacharel Francisco de Moura Escobar e Victoriano Eugenio Marcondes Varella, Hei por bem Conceder à companhia que organizarem privilegio para a construcçāo, uso e gozo de uma estrada de ferro na provincia de Sào Paulo entre Taubaté e Uubatuba e passando por S. Luiz do Parahytinga, e bem assim a garantia de juros de $6 \%$ ao anno sobre o capital que for eimpregado na referida estrada, até o máximo de trinta contos $(30: 000 \$ 000)$, por kilometro nos termos da autorizaçāo conferida ao governo no $\S 1 .^{\circ}$ do art. 7 . da lei n. 3397, de 24 de Novembro do anno proximo passado, sob as clausulas que com este baixam assignadas por Antonio da Silva Prado, Senador do Imperio, do Meu Conselho, Ministro e Secretario de Estado dos Negocios da Agricultura, Commercio e Obras Publicas, que assim o tenha entendido e faça executar. Palacio do Rio de Janeiro em 5 de Janeiro de $1889,680^{\circ}$ da Independencia e do Imperio.

Com a rubrica de SUA MAGESTADE o IMPERADOR 
Vêm a seguir as cláusulas estipulando as condições sob as quais era concedido o privilégio para a construção, uso e gôzo, pelo prazo de 60 anos, da estrada de ferro entre Taubaté e Uubatuba. Além do privilégio concedia o Govêrno outros favores. Cedia gratuitamente, para o leito da estrada, estações, armazéns e outras obras necessárias, os terrenos devolutos nacionais, e bem assim os comprometidos nas sesmarias e posses; concedia o direito de desapropriar aquêles que, de propriedade particular, fôssem necessários para os mesmos fins; permitia o uso de madeiras e outros materiais existentes nos terrenos devolutos nacionais; concedia preferência, em igualdade de condições, para a lavra de minas na zona privilegiada, bem como para a aquisiçāo de terrenos devolutos existentes à margem da estrada, destinados à venda a imigrantes e colonos, de parceria com o Govêrno, sob determinadas condições.

O Govêrno estipulou um prazo de seis meses, a contar da data do decreto, para que fôsse organizada a companhia que deveria construir e explorar a estrada de ferro, sob pena de caducar a concessāo. Outros seis meses para a execuçāo dos estudos definitivos e, aprovados êstes pelo Govêrno, o que deveria ser feito dentro dos 30 dias seguintes à apresentaçäo dos mesmos, obrigar-se-ia a companhia a dar início aos trabalhos de construção dentro de um prazo máximo de 60 dias. Dois anos depois as obras deveriam estar terminadas e em funcionamento a ferrovia.

A estrada de ferro seria de bitola de 1 metro, con linha simples, curvas de raio mínimo de $100 \mathrm{mts}$. e rampas máximas de $3 \%$.

Os concessionários puzeram māos a obra. Foi preciso, porém, que o Govêrno, agora já republicano, a seu pedido, thes concedesse uma prorrogaçāo dos prazos estipulados no contrato. O Decreto 332 , de 12 de abril de 1890 (Diário Oficial da União, de 17 de abril de 1890), aprovou os estudos definitivos, já entāo terminados, e prorrogou até 31 de dezembro de 1891 os prazos para incorporação da companhia e início dos trabalhos de construçāo que, pelo contrato, deveriam terminar em 5 de julho de 1889 e 5 de abril de 1890 , respectivamente.

Organizou-se, entāo, a Companhia Estrada de Ferro Norte de Sāo Paulo. Afinal, em 28 de setembro de 1890, tudo se consolida e a estrada de ferro de Taubaté a Ubatuba pareceu que iria se tornar uma indiscutivel realidade. Nessa data tiveram início, em Ubatuba, os trabalhos de construçāo. Bateu-se a primeira estaca no Indaiá, ao sul da cidade.

Para a cerimônia de início dos trabalhos veiu do Rio de Janeiro, para aquela cidade, luzida comitiva. Viajara a bordo do Juno, novo e elegante vapor, que fazia a sua primeira viagem, construído em estaleiros inglêses, destinado à nossa frota mercante de cabotagem. Do Rio para Uubatuba vieram o dr. Honório Ribeiro, diretor da Companhia Estrada de Ferro do Norte de Sāo Paulo; 
Roberto Normanthon, empreiteiro geral; Cláudio de Vicenzi, diretor da Companhia Navegaçāo Norte e Sul; E. Cox, A. Vale, S. P. Martin, Quintela, Campos Paz, W. H. Ashbrook, Simonetti, Francisco Sampaio, W. Gordon, Mc. Lacklan, D. D. Keay, várias outras pessoas e representantes de quase tôda a imprensa da capital do País. Pelo menos onze jornais cariocas noticiaram circunstanciadamente os acontecimentos.

A comitiva foi recebida em Ubatuba com grande regozijo. Desembarque festivo, passeata, solenidade da inauguraçāo, banquete, lanche, festas à noite e reembarque apoteótico. Da inauguraçāo dos trabalhos foi lavrada uma ata, na Intendência Municipal de Ubatuba. É curto e simples o documento: "Aos vinte e oito de setembro do ano de mil oitocentos e noventa, nesta cidade de Ubatuba, às quatro horas da tarde, na presença de um dos diretores da Companhia, o Exm. ${ }^{\circ}$ Sr. Dr. Honório Augusto Ribeiro, Presidente e Membros da Intendência Municipal, Engenheiro, Autoridades, Membros da Imprensa e grande concurso de pessoas vindas da Capital Federal e moradores dêste Municipio, foram inaugurados os trabalhos da Estrada de Ferro Norte de São Paulo, com tôda solenidade."

Nada mais. Seguiam-se as assinaturas. Assinaram o presidente da Companhia, o presidente da Intendência Municipal, Francisco Gonçalves Pereira; o juiz de direito, Rufino Tavares de Almeida; o vigário, Manuel Macedo Vieira da Rosa; o juiz municipal, Gabriel Olinto de Carvalho e Silva, e muita gente mais. Inclusive o pessoal da comitiva, os representantes da imprensa carioca e a gente tôda da terra. Setenta e uma peșsoas ao todo.

Estavam inaugurados os trabalhos. Um lampejo de esperança fulgiu em Ubatuba, entāo. Infelizmente näo duraria muito. Cêdo viria, novamente, a desilusāo.

O relatório do Ministério da Agricultura, Comércio e Obras Públicas, publicado em 1892, dá uma idéia da situaçāo das obras ao terminar o ano anterior. Fode-se agora ter uma noçāo exata da extensāo da linha. A via principal, entre Taubaté e Ubatuba, deveria possuir $151.799 \mathrm{mts}$. Um ramal, partindo de determinado ponto, alcançaria Sāo Luiz do Paraitinga, com $19.500 \mathrm{mts}$. Ao todo, 171.219 mets. de via férrea deveriam ser construidos pelo Companhia.

Ao terminar o ano de 1891, o leito da ferrovia já ia mais ou menos adiantado na sua construção, estando preparado para receber os trilhos em uma extensāo de $16.500 \mathrm{mts}$. sendo $9.900 \mathrm{mts}$ do lado de Taubaté e $6.600 \mathrm{mts}$ da parte de Ubatuba. Nessa mesma ocasiāo foi resolvido mudar o ponto terminal, da cidade de Ubatuba para a Ponta Grossa, $4 \mathrm{~km}$ distante, por ser êste mais favorável ao estabelecimento de um cais acostável.

Novos informes podem ser obtidos nos relatórios do Ministério da Indústria, Viaçāo e Obras Públicas, referentes aos anos de 
1892 e 1893. Entrado que foi o exercício de 1892, ganharam muito maior impulso os trabalhos de construçāo. A Companhia de Estrada de Ferro Norte viu-se, por sua vez, na contingência de iniciar operações de crédito indispensáveis ao prosseguimento e conclusāo das obras iniciadas.

Nesse ano, o Aviso n. ${ }^{0} 135$, de 27 de agôsto, declarou que o empréstimo que a Companhia poderia levantar seria a da quantia que representasse a diferença entre o capital total - calculado na base de 30 contos por quilômetros, ou sejam 5.130 contos - e o custo das obras até então executadas, e pelo qual o Govêrno já pagava os $6 \%$ de juros da garantia.

A 7 de outubro do mesmo ano, o Aviso n. ${ }^{\circ} 158$ comunicava que a Companhia tinha sido autorizada a levantar um empréstimo de 5.000 contos, correspondente ao total do capital garantido para a construção da estrada de ferro, sem pagamento dos respectivos juros enquanto nāo fôsse aquêle capital empregado nas obras da ferrovia.

Ao terminar o ano de 1892, já existiam $61.500 \mathrm{mts}$ de leito preparado e 45.000 em construçāo. Para o indispensável entroncamento tinham sido já colocadas as agulhas em Taubaté, na Estrada de Ferro Central. Das dez que integravam o projeto, duas estações estavam construidas e uma terceira em construçāo, respectivamente, nos quilometros 12, 22 e 28 , a partir de Taubaté. As duas últimas sāo aquelas que ainda hoje podem ser vistas no povoado do Registro e na Fazenda Fortaleza. A primeira era no Boracéia, no espigāo divisor entre as cabeceiras do Ribeirāo Itaim e o Rio Comprido.

Os trilhos, de aço Bessemer, com $20 \mathrm{k}$. por metro corrido, do tipo Vignole, encontravam-se já no Rio de Janeiro. $O$ material rodante seria semelhante ao da Companhia Mogiana, na época. Seria, ainda, provida a estrada de linhas telegráficas, sendo os aparelhos do sistema Siemens. Uma pequena ponte de $4 \mathrm{mts}$ de vāo e 5 pontilhões estava terminada. Ao todo, 66 boeiros tinham sido construídos.

Vejamos, agora, qual seria, aproximadamente, o traçado seguido pela ferrovia, a partir de Ulbatuba.

A linha tinha seu ponto inicial na Ponta Grossa, promontório, quase peninsula, na baía de Uubatuba, ao sul da cidade. Ali estava localizado o trapiche onde se desembarcava o material destinado à construçāo da estrada, e ali mesmo seria construido, mais tarde, um cais acostável que permitisse o fácil embarque das mercadorias que a estrada Arenaria para a beira-mar.

Partindo da Ponta Grossa, onde a rocha viva fôra rompida a fim de dar passagem ao leito da estrada, a linha dirigia-se para a cidade de Uubatuba, a uns $4 \mathrm{~km}$. Dai procurava, em terrenos quase planos, e em rumo de $70 .^{\circ} \mathrm{S}$. E.. alcançar um dos contrafortes da Serra do Mar, dando início a um grande d senvolvimento de seu 
traçado, a fum de transpor a muralha maritima em rampa que nāo deveria possuir mais que 3\% de aclive. A $854 \mathrm{mts}$ de altitude, no lugar chamado Mocooca, a Serra seria ultrapassada. Até aqui seriam $47.500 \mathrm{mts}$ de percurso, a sua quase totalidade através de matas virgens, boa parte dêles em terras cultivadas com canaviais e mandiocais.

Transposta a Serra do Mar, a estrada desceria pelo vale do Rio Martins, até a sua barra no Paraibuna, a dois quilômetros da entāo freguezia do Bairro Alto. Ali, no $\mathrm{km} \mathrm{61}$, atravessaria o Rio Paraibuna, a $707 \mathrm{mts}$ de altitude. Depois subiria pelo vale do Ribeiräo Corrêa e desceria do outro lado, na vertente do Rio do Peixe, também afluente do Paraibuna. Margeando o Rio do Peixe passaria pela cidade de Natividade e, um quilômetro mais abaixo, atravessaria êste rio, procurando ganhar a Serra da Marmelada (Itambé), no ponto chamado Maná, situado a $825 \mathrm{mts}$ de altitude e a $89 \mathrm{~km}$ da estaca inicial.

Rodando pelo outro lado da serra, a estrada atravessaria o Rio Paraitinga no $\mathrm{km} \mathrm{99}$, a $713 \mathrm{mts}$ de altitude. Esta regiăo era plantada com café, cana e cereais. Depois de cruzar o Paraitinga, a linha caminharia pelo vale do Ribeirāo dos Afonsos até começar a subir de novo, a fim de atravessar a Serra da Quebra Cangalha, no ponto conhecido como Pedra Negra, a $800 \mathrm{mts}$ de altitude, para descer depois para o vale do Rio Unna. A extensāo tôda dêste rio seria vencida quando a estrada atingisse o $\mathrm{km} \mathrm{130,} \mathrm{com} \mathrm{uma} \mathrm{altitu-}$ de de $591 \mathrm{mts}$. Galgaria a estrada mais um obstáculo topográfico, descendo para o vale do Rio Itaí (ou Itaim) e acompanhando-o numa extensāo de $4 \mathrm{~km}$. Depois de atravessá-lo, pela margem ésquerda procuraria o caminho mais curto até o seu ponto terminal, chegando aos armazéns da Estrada de Ferro Central, em Taubaté, com quase $152 \mathrm{~km}$ de percurso total.

O ramal de São Luiz do Paraitinga, que parece nāo foi sequer iniciado, seguiria, provàvelmente, de um modo geral, o atual traçado da estrada de rodagem que ali vai ter, vinda de Taubaté, a partir do lugar chamado Paiol, próximo ao qual se desenvolvia o eixo da linha principal. Um mapa da Viação Férrea paulista, de 1894, permite assim entender a sua locação.

Esta era, mais ou menos, a descriçāo do traçado, segundo os estudos apresentados e aprovados pelo Governo. Algumas alterações, entretanto, durante a execuçāo das obras, foram introduzidas.

Uma das modificações do traçado, por exemplo, diz respeito ao trecho entre Bairro Alto e Natividade. O leito da linha nāo foi construído segundo a descriçāo feita. Em certa altura, depois de Bairro Alto, vindo do litoral, a estrada nāo atravessou nenhum espigāo importante, para ir descer no Rio do Peixe, acima daquela cidade. Seguiu margeando o Paraibuna. Lá estāo ainda hoje os vestígios dos grandes cortes executados. $\mathrm{E}$ foi sair no Rio do Peixe, porém abaixo de Natividade. 
O traçado aprovado previa a perfuraçāo de 48 túneis, dos quais $43 \mathrm{em}$ rocha e $5 \mathrm{em}$ terra. Tratada que foi a empreitada em globo, procuraram os engenheiros dos empreiteiros estudar diversas variantes que melhorassem o traçado. Acharam, assim, uma variante do projeto que suprimia os sete primeiros túneis e dois grandes viadutos. Os viadutos, aliás, seriam, pelo projeto primitivo, em número de 31 , ao todo. Com a variante mencionada, a Serra seria alcançada com a cota de $833 \mathrm{mts}$., em vez de $846 \mathrm{mts}$, muito embora fôsse preciso perfurar um pequeno túnel na encosta do contraforte denominado Jataí.

Ao terminar o ano continuavam as estudos levados a efeito pelos eirgenheiros dos empreiteiros, e esperavam êles, afinal, suprimir os 43 túneis restantes do projeto!...

Das pontes, as mais notáveis, pela sua extensāo, seriam a do Paraitinga e a do Paraibuna; a primeira com $40 \mathrm{mts}$ de vāo e a segunda com $30 \mathrm{mts}$.

$\mathrm{O}$ ano de 1892 foi o que marcou o apogeu da projetada estrada de ferro entre Taubaté e Uubatuba, com ramificação para Sāo Luiz do Paraitinga e possivel prolongamento para os lados de Minas Gerais. Já o ano seguinte, embora de início os trabalhos tivessem decorrido normalmente, nāo foi êle encerrado com chave de ouro. Pelo contrário. $O$ Decreto $\mathrm{n} .{ }^{\mathrm{O}} 1.510$, de 10 de agôsto, prorrogou o prazo para a conclusāo das obras por 24 meses, isto é, até 31 de dezembro de 1895 . Isso parecia dispensável, de vez que prorrogado o prazo para o inicio dos trabalhos para 31 de dezembro de 1891, automàticamente deveria ter-se dado a prorrogaçắo da data da conclusāo para daí a mais dois anos. Entretanto, assim nāo entendeu o Govêrno, como adiante veremos.

A primeira seçāo da estrada, desde Taubaté até o $\mathrm{km} \mathrm{40,} \mathrm{es-}$ tava terminada em 1893. Na segunda seçāo, entre o $\mathrm{km} 40$ e o $\mathrm{km} 841 / 2$, estavam também terminados os movimentos de terra, bem como as obras de arte até o $\mathrm{km} \mathrm{56}$. A terceira seção, entre o $\mathrm{km} 841 / 2$ e o $\mathrm{km} \mathrm{104,} \mathrm{trecho} \mathrm{que} \mathrm{atravessava} \mathrm{o} \mathrm{alto} \mathrm{da} \mathrm{Serra,}$ possuia apenas dois quilômetros de leito terminado. No restante, a exceção do trecho entre Uubatuba e a Ponta Grossa, pouca coisa fôra feito. De um modo geral, estavam terminados $84 \mathrm{~km}$ do traçado, prontos para receber a via permanente. A casa de máquinas, em Taubaté, fôra também construída.

Grandes dificuldades econômicas enfrentava a Companhia Estrada de Ferro Norte de Sāo Paulo. Por falta de pagamento, em junho e julho de 1893, dissolveu-se o pessoal técnico da companhia empreiteira das obras. Apesar disso, alguns sub-empreiteiros continuaram trabaihando até o dia 31 de dezembro, quando. receberam ordem para suspender suas atividades. Estes ficaram sem receber, por certo, visto que a Companhia nāo mandou proceder às medições dos trabalhos executados. Apenas alguns traba- 
lhadores continuavam na baixada litorânea. Nunca mais aquelas obras teriam prosseguimento.

Em 2 de junho de 1894 foi passada a sentença de morte da - Companhia Estrada de Ferro Norte de São Paulo: o Decreto n. ${ }^{\circ}$ 1.721, daquela data, declarava caducos o privilégio, a garantia de juros e mais favores concedidos para a construçāo, uso e gôzo da estrada de ferro de Taubaté a Ubatuba. Não entendera o go- vêrno que a prorrogação concedida para o início dos trabalhos - de 5 de abril de 1890 para 31 de dezembro de 1891 - implicava também em uma prorrogaçāo automática do prazo pára a conclu- sāo das mesmas. Dessa forma, ao conceder a prorrogaçāo de dois anos - especificadamente para a conclusāo das obras - não a entendeu senéo como terminado o último prazo em 5 de abril de 1894. E decorrido aquêle prazo, nem sequer dois meses esperaria, tornando caduca a concessão.

À suspensāo dos trabalhos, efeito e nāo causa, sucedeu o completo aniquilamento da Companhia e a consequisente ruina do Banco Popular de Taubaté, com prejuizo completo para todos os acionistas e depositantes.

Fassaram-se alguns anos. Francisco Ribeiro de Moura Escobar fêz ainda uma tentativa para ressuscitar a estrada. Dirigiu um memorial ao Govêrno pleiteando a revogaçāo do decreto que declârara caduca a concessão. Alegava êle que aquela decisāo do Govêrno fôra antecipada sem razāo. Faltavam ainda - no seu modo de entender - 10 meses e 21 dias para expirar o prazo marcado para a conclusāo das obras quando, intempestivamente, decreta o Govêrnó a cassaçāo do privilégio e demais favores. Faz sentir que os trabalhos, na ocasiäo, "prosseguiam com relativa regularidade". Referia-se, por certo, aos poucos homens que trabalhavam a vertente atlântica. Mas alegava também, e com justa razāo, a situação de sérias dificuldades econômicas que o país atravessava entāo, "agravadas pela revolta da Armada (1893), óbices que entorpeceram a marcha de todos os ramos da vida nacional; óbices que levaram à paralização e à ruína crescido número das mais prósperas e abastadas emprêsas do país; óbices que forçaram, pouco depois, a Administraçāo Federal a suspender quantos trabalhos públicos fôssem passiveis dessa extrema soluçāo; que obrigaram o Congresso a aumentar em vexatórias proporções as contribuições públicas; e. finalmente, coagiram o govêr.no da Uniāo à premente e penosa contingência de subscrever o contrato do Funding Loan".

Debalde alegou Moura Escobar que "organizada a Compa-nhia e iniciada a construçāo das obras, prosseguia ela sem a menor irregularidade, conforme atesta a ausência absoluta de multas até entāo, quando surgiram as dificuldades originais da intensa crise financeira que se manifestou em seguimento ao chamado $\mathrm{Pe}$ ríodo do Encilhamento". De nada valeram seu reclamos. Estava 
liquidada, definitivamente liquidada, a Companhia Estrada de Ferro Norte de Sāo Paulo, e com ela a ferrovia Taubaté-Ubatuba.

Vários sāo, hoje em dia, os motivos alegados e em razāo dos quais teria sido levado o Govêrno da República a usar daquele drástico tratamento para com a concessionária da linha férrea do Paraiba ao Litoral. Dizem uns que se deve atribuir o fato à pressāo exercida pela Inglêsa (S.P.R.), de vez que a linha projetada drenaria boa parte dos seus fretes entre o planalto e a beira mar. Querem outros atribuir o sucedido a um puro e simples fracasso de emprêsa industrial. Levam outros as causas a fatos de ordem politica, aduzindo a versāo de que tendo sido um dos dirigentes da Companhia, ou um dos concessionários da estrada, simpático aos revoltosos de 1893, vingara-se Floriano Peixoto fazendo caducar a concessāo.

Aliás, em certa passagem daquele discurso de Esteves da Silva, atrás referido, na câmara estadual, pode-se vislumbrar certa insinuaçāo, en abôno desta última versāo. Propondo a criaçāo de núcleos coloniais no litoral, mostrava o estado de decadência a que atingira a regiāo. Tudo possuira. Nada mais tinha entāo. Até uma estrada de ferro estivera sendo construida. E narra, resumidamente, o fim da mesma: "Fêz-se un cais aberto na rocha viva, preparou-se o leito todo da estrada, construiram-se até estações elegantes com armazéns, como poderāo atestar alguns colegas, aplicaram-se os trilhos e, afinal, a infeliz revolta de 1893, por motivos que nāo vem ao caso expor, deu causa à caducidade da concẹssāo (o grifo nāo é da citaçāo), que foi o tiro de morte para aquela localidade".

O entusiasmo e a ansiedade que se apossaram da populaçāo local, desde o início e enquanto perduraram os trabalhos de construção da ferrovia para Taubaté, parece nāo terem tido símile em tôda a história de Ubatuba. E a desilusāo e o abatimento foram, por isso mesmo, extremos. Nada mais deteve a decadência, vivida em um crescendo ininterrupto, desde então até quase nossos dias. Se hoje Ubatuba apresenta indícios de certa recuperaçāo, de forma alguma essa revitalização pode ser comparada com a prosperidade e o fastígio atingidos em épocas anteriores, quando suas rendas públicas chegaram a superar às da própria capital paulista.

Os contemporâneos, ainda sobreviventes, daqueles três anos de atividades, quando Ubatuba esteve na iminência de reatar sòlidamente seus laços econômicos com a regiāo situada à retaguarda da Serra do Mar, da da Quebra Cangalha e, provàvelmente, da da Mantiqueira, lembram-se saudosos da azáfama e do lufa-lufa que ia por tudo ali. Eram os navios que chegavam a descarregar material no trapiche da Ponta Grossa; eram os quilometros de leito já preparados na baixada litorânea, com os trilhos estendidos, as obras de arte já prontas, trafegados pelos troles de linha, impulsionados a varejāo, pelos trabalhadores da estrada. Grande mo- 
vimento de gente: engenheiros, empreiteiros, trabalhadores, tudo dando vida ao lugar e movimentando o comércio local.

De uma hora para outra - passada a fase de maior atividade, entre 1892 e 1893 - a síncope sobreveiu. Foi como que uma embolia econômica, obstruindo os meios de circulaçāo financeira. $O$ ritmo de atividade foi interrompido. Ubatuba mergulharia no marasmo. A culpa, para muitos, nāo fôra de outros, senāo do govêrno. A culpa maior. $O$ resto, consequiencia. Em épocas difíceis, um fato puxa o outro. $\mathrm{E}$ para os que viveram aquêle indelével momento histórico, outra razāo para os fatos supervenientes nāo pudera ser encontrada. Por isso que, em seu número de 7 de março de 1897, o "Echo Ubatubense", hebdomadário local, trazia um artigo, assinado por Esteves da Silva, no qual, entre outras coisas, assinalava o que ai está dito...

"O desalento, a desorganizaçāo e o abandôno, conseqüências naturais da injustiça e êrro administrativo com que fizeram interromper a construção da estrada de ferro, adiantadissima, de Taubaté a Ubatuba, a desorientaçāo e a pobreza lavrando em todo o município, pelos prejuizos sofridos pela populaçāo, por quase tôdas as classes, pela falência da Companhia Norte de São Paulo, deixando-se de pagar as pequenas soldadas dos operários, filhos da localidade, e os negociantes, seus fornecedores, tudo isso e mais ainda o descalabro e abatimento, derivados do estado de sítio que havia horrorizado ' $e$ ainda mais empobrecido o litoral, tornaram impossivel do lado da populaçāo qualquer esfôrço capaz de resistir à torrente destruidora." Além do choque econômico, as complicaçóes políticas decorrentes da revolta da Armada. Tudo se acumpliciou para dar ao litoral norte o empurrão último que haveria de projetá-lo no abismo da decadência irremediável.

Nada e de mais ninguém tinha Ubatuba a esperar. Nāo a socorresse o govêrno do Estado e a miséria continuaria imperando. Ubatuba, que já se erguera altaneira e rica, entre as vilas e cidades da Provincia que mais o fôssem, passou a mendigar até miseráveis subvenções para a navegaçāo com 0 pôrto de Santos, isolada que ficara do restante do território paulista. É o mesmo "Echo Ubatubense", de 8 de agôsto de 1897 quem nos trás o tetemunho daquela triste realidade.

"E Ubatuba, que outrora, antes da trafegaçāo da Central, era uma das principais artérias comerciais da provincia paulista e do rico sul de Minas e que em movimento e mesmo em rendas aduaneiras rivalizava com a praça de Santos, se é que em muitos pontos a nāo sobrepujava, pode ser considerada hoje, pela uberdade de suas terras, pela excelência de seu clima, pela importância e capacidade de seu pôrto, pela sua posiçāo estratégica no extremo norte do Estado, como uma riqueza estéril, inútil e até pesada aos cofres públicos, pelo isolamento em que se acha, conseqüência de 
longo abandôno em que a tem deixado os que tem a responsabilidade do poder.

"Jaz insulada do resto do Estado por mar e por terra; por mar, porque suas comunicações com Santos se fazem hoje como se faziam há uns pares de milheiros de anos: - por canoas, viagens cujos perigos sāo fáceis de imaginar; por terra, porque as suas estradas sāo verdadeiras picadas, cujos concertos se tornam inúteis, pois que, abandonadas a si mesmas, sem pessoal de conserva, vem logo as enxurradas e a vegetaçāo obstrui-las por completo." $\mathrm{E}$ prosseguia o articulista para, afinal, apelar para o presidente do Estado, entāo Campos Sales, no sentido de que o govêrno subvencionasse uma navegaçāo regular com o pôrto de Santos, mesmo com apenas quatro viagens mensais...

E durante quase meio século, dai em diante, Uubatuba não possuiu senāo uma precaríssima navegaçāo subvencionada. E deveria ainda se dar por muito feliz quando assim fôsse, porque durante largo período nem isso chegou a ter.

Os anos passaram. As obras continuaram abandonadas, o material largado. Com o tempo foi se estragando. Uma parte dos trilhos lá deixados, tomou rumo.

Foi o caso de que, certa feita, andava o dr. Antônio Paes de Barros Sobrinho em dificuldades para conseguir trilhos para um ramal de lenheiro, na Companhia Paulista, que pretendia abrir, se nāo nos enganamos, para os lados de Morro Grande, próximo a Rio Claro. Também, se nāo nos falha a memória, era pelo tempo da guerra de 1914, quando a importação dêsse material tornara-se impossível. Veiu a saber, entäo, que em Ubatuba encontravamse os restos do material empregado na construçāo da estrada de ferro para Taubaté. Depois dos entendimentos necessários - contou-nos aquêle saudoso paulista - foi ter a Santos. As dificuldades de transporte conseguiu superá-las graças ao fato de ter encontrado à venda, um pequeno barco a vela e a motor. Adquirindo-o, abriu os panos rumo de Ubatuba, onde carregou a embarcaçăo com os trilhos, levantando ferros para Santos, de volta. Ai chegado, por sorte, negociou a embarcação novamente, com lucro ainda. Ficara de graça a viagem, e muito barato os trilhos.

Quando por volta de mil novecentos e vinte e tantos, foi instalada luz elétrica em Ubatuba, os trilhos que ainda por lá existiam foram aproveitados para postes. E nessa funçāo ainda continuam.

Esta, mais ou menos, a história da estrada de ferro TaubatéUbatuba, da qual era concessionária a Companhia Estrada de Ferro Norte de São Paulo. Duas outras vêzes, pelo menos, esteve em foco a questāo da ligação ferroviária de Ubatuba com a vale do Paraiba e sul de Minas.

Uma delas diz respeito à concessāo do privilégio, à Companhia do Pôrto e da Estrada de Ferro Nordeste de São Paulo, pelo 
prazo de 60 anos, para a construçāo, uso e gôzo de uma ferrovia que, partindo de Ubatuba e passando por Taubaté, alcançasse a cidade de Faraisópolis, em Minas Gerais, sem ônus algum para a Uniāo. Essa concessāo foi obtida pelo Decreto n. ${ }^{0} 12.362$, de 10 de janeiro de 1917. Afirma Félix Guisard que a concessionária desenvolveu grande trabalho em Londres, junto a Ulnion Railway Company Limited, a fim de levar avante a empreitada, mal sucedido em conseqüência da guerra. $O$ fato é que, mesmo com as sucessivas prorrogações de prazo concedidas pelo Govêrno Federal, em vista da conflagração mundial, prazos êsses que vieram a correr sòmente depois da assinatura do armistício, e mesmo da do tratado de paz, nem assim conseguiu a mencionada Companhia entrar em forma para o início dos trabalhos. Ainda em 1922 o Govêrno concedeu novo prazo de 5 anos. Nem assim. Por isso, resolveu o govêrno provisório, em 6 de dezembro de 1931, declarar nula, pelo Decreto n. ${ }^{\circ} 26.587$, a concessāo para a construçāo da estrada de ferro Ubatuba-Paraisópolis, via Taubaté. Tinha se encerrado, com a implantação do regime de 1930 - simbòlicamente configurado nesta declaraçāo de caducidade - o ciclo febril das construções ferroviárias no país, e cujo apogeu deve ser levado ao crédito dos eminentes estadistas do fim do Império e comêço da República.

A outra diz respeito a uma pretendida concessāo, entretanto nāo obtida, para a construçāo de uma estrada de ferro entre Ubatuba e Cruzeiro. A estrada, segundo o projeto, subiria a Serra pelo lado norte de Ubatuba, mais ou menos pelas vertentes do Rio Ubatuba e Indaiá (Barra Sêca), indo alcançar a parte superior do vale do Paraibuna e, transposto êste, entrar no do Paraitinga. Subiria pelo Paraitinga, desde abaixo de Cunha, deixaria Campos de Cunha à direita e atravessaria a Quebra Cangalha para descer perto de Cachoeira e daí alcançar Cruzeiro. Nāo saiu do papel. 